\title{
Differential Gene Expression in the Model Actinomycete Streptomyces coelicolor A3(2) Supports Nitrogen Mining Dependent on the Plant Carbon to Nitrogen Ratio
}

\author{
Damien Finn ${ }^{1,2, *}$, Kerrilyn Catton ${ }^{3}$, Marijke Heenan ${ }^{3}$, Peter M. Kopittke ${ }^{1}($, \\ Diane Ouwerkerk $^{4,5}$ (D), Athol V. Klieve ${ }^{1,5}$ and Ram C. Dalal ${ }^{1}$ (D) \\ 1 School of Agriculture and Food Sciences, The University of Queensland, Brisbane, QLD 4072, Australia; \\ p.kopittke@uq.edu.au (P.M.K.); a.klieve@uq.edu.au (A.V.K.); r.dalal@uq.edu.au (R.C.D.) \\ 2 School of Life Sciences, Arizona State University, Tempe, AZ 85281, USA \\ 3 Soil Chemistry Lab, Department of Science, Technology and Innovation, Queensland Government, Brisbane, \\ QLD 4001, Australia; Kerrilyn.catton@des.qld.gov.au (K.C.); marijke.heenan@des.qld.gov.au (M.H.) \\ 4 Rumen Ecology Unit, Department of Agriculture and Fisheries, Queensland Government, Brisbane, \\ QLD 4001, Australia; Diane.Ouwerkerk@daf.qld.gov.au \\ 5 Queensland Alliance for Agriculture and Food Innovation, The University of Queensland, Brisbane, \\ QLD 4072, Australia \\ * Correspondence: damien.finn@uqconnect.edu.au; Tel.: +1-480-331-0302
}

Received: 19 September 2018; Accepted: 5 December 2018; Published: 6 December 2018

\begin{abstract}
Nitrogen mining is the process whereby microbial communities catabolise recalcitrant long-term organic matter $(\mathrm{OM})$ to meet nutritional requirements that are not ensured by labile OM. Microbial degradation of recalcitrant OM impacts soil fertility and contributes to greenhouse gas emissions in agricultural systems. Here we conducted a transcriptomics study to track differential gene expression in the model soil Actinomycete Streptomyces coelicolor A3(2) during the decomposition of mung bean (Vigna radiata L.) and wheat (Triticum aestivum L.) residues of relatively low and high carbon-to-nitrogen (C:N) ratios (17.3 and 35.7, respectively) at 1, 7, and 14 days of incubation. A negative binomial general linear model showed that plant variety predominantly affected transcription $(p<0.001)$, although time of incubation also had an effect $(p=0.01)$. In the high C:N ratio treatment, the expression of cellulases, chitinase, $\mathrm{N}$-acetylglucosaminidase, secreted peptidases, and mineral nitrogen $(\mathrm{N})$ metabolism were increased after $24 \mathrm{~h}$. The low C:N ratio treatment demonstrated preferential expression of glutamate dehydrogenase, transporters involved in glutamate uptake and glycolysis, indicating more efficient $\mathrm{N}$ and carbon (C) assimilation. After 14 days, the low $\mathrm{C}: \mathrm{N}$ ratio treatment showed increased transcription of extracellular enzymes, glutamate dehydrogenase, and glutamate transport. These results show an important role for added plant organic $\mathrm{N}$ content in determining when the transcription of genes associated with $\mathrm{N}$ mining occurs.
\end{abstract}

Keywords: plant decomposition; soil organic matter; soil microbial function

\section{Introduction}

It is well-documented that the conversion of native vegetation for agricultural land use leads to losses of $25-50 \%$ of soil organic carbon (SOC) [1]. Losses of SOC and the associated nitrogen (N) and phosphorus $(\mathrm{P})$ (collectively referred to here as soil organic matter or SOM) from agricultural soils threatens future food security due to decreases in crop productivity, increased soil erosion, and is a net source of atmospheric greenhouse gases [2-4]. Microbial metabolism converts input organic 
matter to form stable, long-term metabolites adsorbed to soil particles, which could be a means to restore SOM in agricultural systems [5-7]. This SOM can be further metabolised (and therefore not retained) to meet cellular requirements in N-poor systems. This process is referred to as $\mathrm{N}$ mining, which is characterised by a net increase in decomposition as microorganisms degrade recalcitrant organic matter $(\mathrm{OM})$ to acquire $\mathrm{N}$ [8-10]. Consequently, the carbon-to-nitrogen (C:N) ratio of input organic matter can affect the retention of SOM $[8,11,12]$.

Bacterial taxa within the phylum Actinobacteria are often observed to be relatively more abundant in agricultural soils compared to other phyla [13-15]. Members of the order Actinomycetales, in particular, are ubiquitous within soil, water, and plant litter environments, and have long been considered to play an important role in carbon (C) cycling [16]. Streptomyces coelicolor A3(2) has been studied extensively by the scientific community [17] and the $8.67 \mathrm{Mbp}$ linear genome of S. coelicolor A3(2) has been sequenced and annotated [18]. The majority of this microorganism's genome is devoted to the regulation, transportation, and degradation of extracellular nutrients, and it is well adapted to the spatially heterogeneous and temporally variable soil environment [18]. Metabolic analyses have observed sensitivity to nutrient availability, with switches from the Embden-Meyerhof-Parnas pathway to the pentose phosphate pathway when transitioning from exponential to stationary growth [19], in addition to significant changes in the regulation of $\mathrm{N}$ and $\mathrm{P}$ metabolism during this transition [20]. Both genomic and metabolic analyses support the utilisation of a variety of $C$ sources by S. coelicolor A3(2), such as glucose, cellulose, cellobiose, xylose, glycerol, galactose, fructose, arabinose, chitin, and $\mathrm{N}$-acetyl glucosamine $[18,19]$. The metabolic diversity and strict metabolic regulation of this soil microorganism make it an ideal candidate to better study $\mathrm{N}$ mining responses in a model system.

The objective of this study was to study differential gene expression (DGE) in S. coelicolor A3(2) during the decomposition of plant material with varying $\mathrm{N}$ concentrations. These were: (a) wheat (Triticum aestivum L.) (C:N ratio 35.7); and (b) mung bean (Vigna radiata L.) (C:N ratio 17.3). Differential gene expression was compared over time (at 1, 7, and 14 days of incubation). We hypothesised that S. coelicolor A3(2) would undergo significant transcriptional changes in response to plant material with varying $\mathrm{C}: \mathrm{N}$ ratios, targeted at greater acquisition and catabolism of $\mathrm{N}$ sourced from native SOM in response to wheat, relative to mung bean.

\section{Materials and Methods}

\subsection{Soil and Plant Sampling}

Soil, an alfisol, was collected from a long-term phosphorus fertilisation trial in Horsham, Australia $\left(-36.672547^{\circ} \mathrm{N}, 142.288467^{\circ} \mathrm{E}\right)$. A bulk soil sample was taken from the top $0-10 \mathrm{~cm}$ depth. Soil was homogenised and dried at $40^{\circ} \mathrm{C},>2 \mathrm{~mm}$ root material was removed, ground, and passed through a $<2 \mathrm{~mm}$ sieve. Soil particle size analysis, Colwell-phosphorus (Colwell-P) extraction $\left(\mathrm{NaHCO}_{3}\right.$ at $\mathrm{pH}$ 8.2), $\mathrm{pH}$, and electrical conductivity (EC) were measured as described in Reference [21], with $\mathrm{pH}$ and EC measured using a 1:5 soil-to-water suspension. Field capacity moisture (FCM) was determined using the container capacity method, which is equivalent to $55-75 \%$ water-filled pore space [22]. The soil texture was as follows: $48.6 \%$ sand, $33.3 \%$ silt, and $18.1 \%$ clay. The Colwell-P concentration was $22 \mathrm{mg} \mathrm{kg}^{-1}$ soil. The soil $\mathrm{pH}$ was 5.5. The EC was $0.1 \mathrm{mS} \mathrm{dm}^{-1}$ and the FCM was $36.5 \%$. A soil subsample was ground to $<100 \mu \mathrm{m}$ particle diameter and total $\mathrm{C}$ and $\mathrm{N}$ was measured on a TruMac CN analyser (LECO, Castle Hill, Australia). The soil total organic carbon (TOC) was 6\%, and total nitrogen (TN) was $0.48 \%$ (C:N ratio of 12.5). To homogenise the plant material, it was dried at $60^{\circ} \mathrm{C}$ for $72 \mathrm{~h}$ prior to freezing at $-17^{\circ} \mathrm{C}$ for $24 \mathrm{~h}$. The plant material was subsequently freeze-dried with a primary stage at $0{ }^{\circ} \mathrm{C}$ for $24 \mathrm{~h}$ and a secondary stage at $30^{\circ} \mathrm{C}$ for three days. The dried material was ground to $<100 \mu \mathrm{m}$ particle diameter. The $\mathrm{C}$ and $\mathrm{N}$ contents of plant residues were $42.8 \%$ and $1.2 \%$ in wheat (C:N ratio of 35.7 ), and $38 \%$ and $2.2 \%$ in mung bean (C:N ratio of 17.3 ), respectively. 


\subsection{Bacterial Strain and Culture Conditions}

S. coelicolor A3(2) was obtained from the American Type Culture Collection (ATCC), ATCC identification no.: BAA-471. The organism was cultured on ATCC medium 1877, ISP medium 1 (tryptone-yeast extract) and dextrose-starch agar (Becton-Dickinson, Franklin Lakes, NJ, USA) at $28^{\circ} \mathrm{C}$. To identify the exponential growth phase, a growth curve assay was performed at $0,1,3,7,14$ and 20 days with a LIUV-201 UV/Vis spectrophotometer at $600 \mathrm{~nm}$ (Lambda Scientific, Edwardstone Town, Australia).

\subsection{Soil Incubation}

A subsample of soil was treated with gamma-irradiation to a total gamma-ray dosage of $35 \mathrm{kGy}[23,24]$. A total of $2 \mathrm{~g}$ of gamma-irradiated soil and $200 \mathrm{mg}$ of either ground wheat or mung bean material (10\% weight/weight) were added to a sterilised gas-tight Hungate tube (Bellco, Vineland, NJ, USA). Once S. coelicolor A3(2) had reached the beginning of the exponential growth phase, cells were washed twice with $5 \mathrm{~mL}$ sterile $10 \mathrm{mM}$ potassium phosphate buffer (PPB) (pH 6.8) by centrifugation at $3000 \times g$ for $10 \mathrm{~min}$ and resuspended in $1 \mathrm{~mL} 10 \mathrm{mM}$ PPB. To bring the soil to field capacity moisture, 720 microlitres of $S$. coelicolor A3(2) cells resuspended in $10 \mathrm{mM}$ PPB were added to the treatments. Negative controls were prepared by adding $720 \mu \mathrm{L} 10 \mathrm{mM}$ PPB to duplicate gamma-irradiated soil samples. All incubations were performed in triplicate. Final sample weights were noted to readjust moisture levels with $10 \mathrm{mM}$ PPB over time. Incubations were performed statically at $28^{\circ} \mathrm{C}$.

\subsection{RNA Extraction, Sequencing, and DGE Analysis}

Incubated soils were resuspended in $4 \mathrm{~mL}$ of $10 \mathrm{mM} \mathrm{PPB}$, aliquoted separately in $1 \mathrm{~mL}$ volumes, and preserved by snap-freezing on liquid nitrogen. Total RNA was extracted from $1 \mathrm{~mL}$ soil resuspensions at time points 1,7 , and 14 days with MoBio RNA Powersoil Total RNA Isolation kits (MoBio Laboratories, Carlsbad, CA, USA), in accordance with the manufacturer's instructions. Extracted RNA was treated with RNase-free DNase I (New England Biolabs, Ipswich, MA, USA). Messenger RNA library preparation and transcriptomic sequencing on the Illumina HiSeq High Throughput platform with $150 \mathrm{bp}$ single read chemistry was performed by the Australian Genome Research Facility (AGRF, Melbourne, Australia). All statistical analyses were performed in R version 3.4.1 [25]. For DGE analyses, sequencing data was first run through Trimmomatic [26] and FastQC (www.bioinformatics.babraham.ac.uk/projects/fastqc/) for quality control purposes. Bowtie2 [27] was used to align reads to the S. coelicolor A3(2) genome with local alignment and zero mismatches to improve the stringency of read mapping. SAMtools [28] was used to convert the output of Bowtie2 to the BAM format. In R, DESeq2 was used as described in Reference [29]. Sequence counts below 20 were filtered out. From the results of the S. coelicolor A3(2) DGE analyses, pairwise comparisons of $\mathrm{C}$ and $\mathrm{N}$ metabolism were conducted via Student's $t$-tests, using the plant substrate as a categorical variable. A negative binomial general linear model was used to compare the effects of the $\mathrm{C}$ and $\mathrm{N}$ metabolism genes with time and plant substrate [30]. Finally, the sequence data was archived with the European Nucleotide Archive with the Project ID: PRJEB23455.

\section{Results}

A transcriptomics approach centred on the metabolism of S. coelicolor A3(2) in gamma-irradiated soil was chosen in this study for several reasons. Firstly, shotgun metagenomics approaches in soils are plagued by both low rates of annotation and low sequencing coverage due to the enormous biodiversity inherent in soil ecosystems. Secondly, the genomics of S. coelicolor A3(2) have been exhaustively studied due to its industrial applications as an antibiotic producer [20], as a model organism in terms of genetic regulation [17], and as a model organism for life in soil [18]. Consequently, it has been possible to explore the DGE of potential genes associated with $\mathrm{N}$ mining in greater detail 
than would be possible by considering the shotgun metagenomics of a complex microbial community during plant decomposition.

The total sequences per sample were $13.17 \pm 1.8$ million, and total number of reads passing Trimmomatic was $99.68 \pm 0.1 \%$. Of the 6123 non-zero S. coelicolor A3(2) transcriptional reads, $755(12.3 \%)$ demonstrated a significant log-fold increase $(p<0.05)$, and $763(12.5 \%)$ demonstrated a significant log-fold decrease $(p<0.05)$ between treatments and over time. A collection of genes encoding for transcriptional regulators involved in nutrient sensing and membrane transport, and extracellular enzymes involved in nutrient acquisition, and core $\mathrm{C}$ and $\mathrm{N}$ metabolism were chosen for in-depth analyses (Figure 1). A negative binomial general linear model of the log-fold change in the expression of these genes showed strong differences between plants $(p<0.001)$, and to a lesser extent over time $(p=0.01)$.

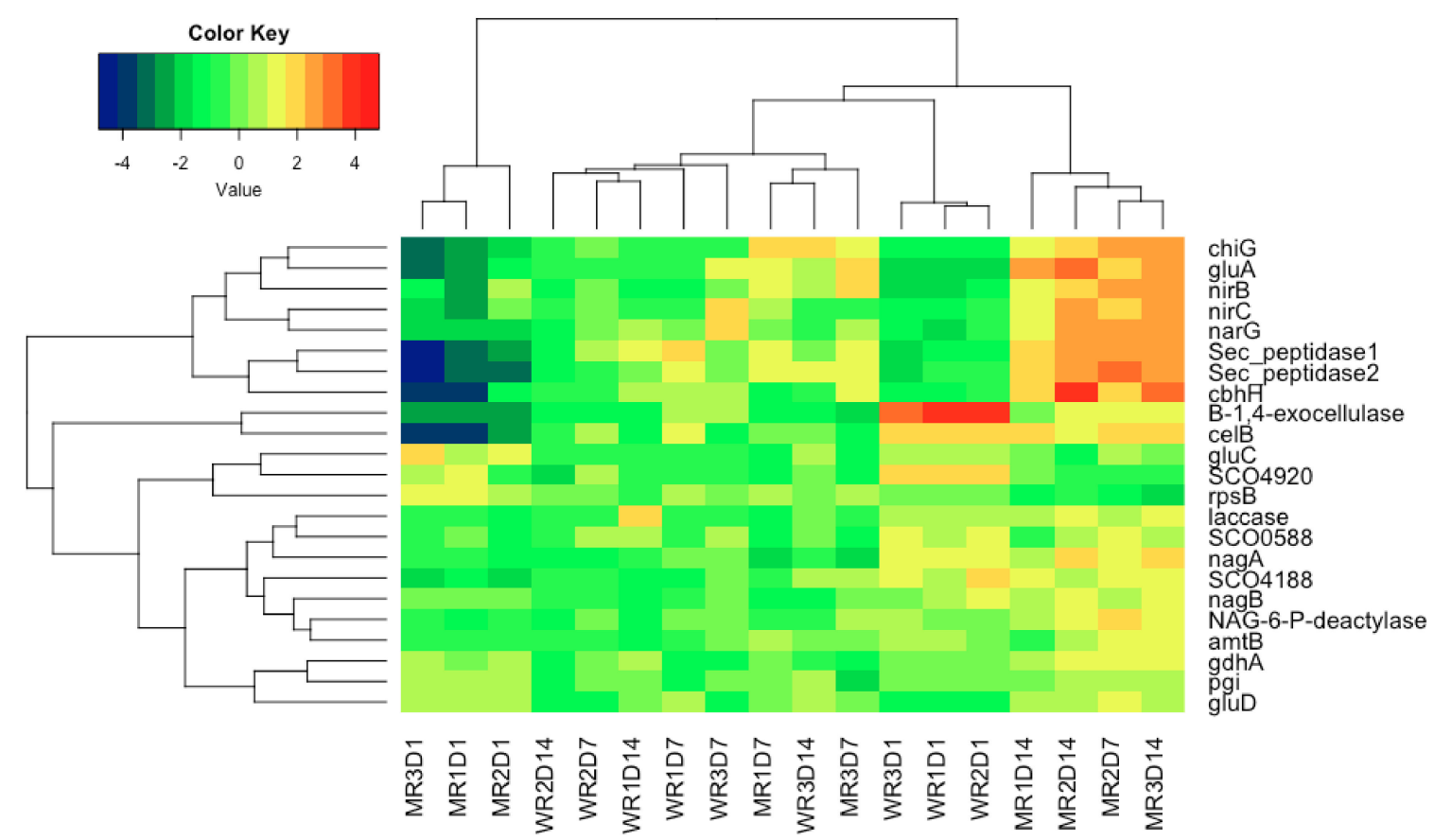

Figure 1. Heatmap of log-fold change (LFC) comparisons of differential gene expression of S. coelicolor $\mathrm{A} 3(2)$ regulation, extracellular enzymes, and core $\mathrm{C}$ and $\mathrm{N}$ metabolism genes. A relative decrease in LFC is dark blue, while increases are red. Sample names are coded as follows: M (mung bean); W (wheat); R (replicates 1, 2, and 3); D (days 1, 7, and 14). Dendrograms are based on sample similarity (x-axis) and gene expression similarity (y-axis).

After $24 \mathrm{~h}$ of incubation, the DGE of S. coelicolor A3(2) was highly supportive of the $\mathrm{N}$ mining hypothesis. The relatively high C:N ratio of the wheat substrate elicited increased expression of a number of extracellular enzymes involved in $\mathrm{C}$ and $\mathrm{N}$ acquisition from plant material and SOM (cellulases celB and a putative beta-1,4-exocellulase, chitinase chiG, $\mathrm{N}$-acetyl glucosaminidase nagA, a secreted peptidase, and lignin-degrading laccase) and increases in mineral $\mathrm{N}$ metabolism (nir C) and ammonium uptake from the environment via the ammonium transporter amtB (Table 1). The increased transcription of extracellular enzymes involved in $\mathrm{N}$ metabolism was reflected by the transcription of several regulators fundamental to regulating $\mathrm{N}$ metabolism in S. coelicolor A3(2), such as: (a) the upregulation of the nutrient availability sensor and CAZy regulator SCO4920 [31]; (b) the upregulation of the mineral $\mathrm{N}$ metabolism regulator SCO0588 [32]; and (c) the upregulation of the nutrient availability sensory and developmental regulator SCO4188 [33]. 
Table 1. Log fold change (LFC) comparisons of the differential gene expression of S. coelicolor A3(2). The mean and standard deviation of three replicates are shown for wheat and mung bean treatments. Student's $t$-tests were performed to compare treatments separately for days 1, 7, and 14. Significantly different LFCs are noted as: $p<0.05\left(^{*}\right) ; p<0.01(* *) ; p<0.001(* * *)$.

\begin{tabular}{|c|c|c|c|c|c|c|c|c|c|c|}
\hline \multirow[b]{2}{*}{ Category } & \multirow[b]{2}{*}{ Gene } & \multicolumn{3}{|c|}{ Day 1} & \multicolumn{3}{|c|}{ Day 7} & \multicolumn{3}{|c|}{ Day 14} \\
\hline & & Wheat & Mung Bean & Average LFC & Wheat & Mung Bean & Average LFC & Wheat & Mung Bean & Average LFC \\
\hline \multirow[t]{3}{*}{ Regulation } & SCO4920 deoR-family reg & $2.07 \pm 0.2$ & $0.71 \pm 0.4$ & $1.36^{*}$ & $-0.15 \pm 0.9$ & $-1.05 \pm 0.3$ & 0.9 & $-0.61 \pm 0.9$ & $-0.46 \pm 0.4$ & 0.14 \\
\hline & SCO4188 gntR-family reg & $1.25 \pm 0.4$ & $-1.77 \pm 0.2$ & $3.01 * *$ & $-0.63 \pm 0.6$ & $0.97 \pm 0.6$ & $1.6^{*}$ & $-0.48 \pm 0.9$ & $1.25 \pm 0.4$ & 1.73 \\
\hline & SCO0588 sensor kinase & $1 \pm 0.46$ & $-0.72 \pm 0.7$ & $1.72 *$ & $0 \pm 0.5$ & $-1.47 \pm 0.1$ & $1.47^{*}$ & $-0.02 \pm 0.6$ & $0.27 \pm 0.8$ & 0.29 \\
\hline \multirow[t]{4}{*}{ Membrane } & SCO5583 amtB & $0.36 \pm 0.3$ & $-0.38 \pm 0$ & 0.74 * & $-0.51 \pm 0.6$ & $0.52 \pm 0.4$ & 1.03 & $-0.7 \pm 0.4$ & $0.38 \pm 1$ & 1.07 \\
\hline & SCO2831 gluA & $-1.8 \pm 0.2$ & $-2.39 \pm 1$ & 0.58 & $-0.42 \pm 0.1$ & $1.5 \pm 0.4$ & $1.92^{* *}$ & $-0.11 \pm 0.6$ & $2.76 \pm 0.4$ & $2.87^{* *}$ \\
\hline & SCO5775 gluC & $0.69 \pm 0.1$ & $1.29 \pm 0.5$ & 0.61 & $-0.56 \pm 0.1$ & $-1.01 \pm 0$ & 0.45 & $-0.26 \pm 0.5$ & $0.67 \pm 0.1$ & 0.19 \\
\hline & SCO5774 gluD & $-1.28 \pm 0.1$ & $0.67 \pm 0.1$ & $1.94^{* * *}$ & $-1.11 \pm 0.1$ & $0.42 \pm 0.7$ & $1.53^{*}$ & $-0.31 \pm 0.7$ & $0.6 \pm 0.3$ & 0.92 \\
\hline Extracellular & SCO7176 Sec peptidase 1 & $-1.39 \pm 0.4$ & $-3.53 \pm 1.3$ & 2.14 & $0.8 \pm 0.9$ & $1.7 \pm 0.8$ & 0.9 & $-0.06 \pm 1$ & $2.48 \pm 0.5$ & 2.54 * \\
\hline \multirow[t]{7}{*}{ Enzymes } & SCO7188 Sec peptidase2 & $-1.08 \pm 0.8$ & $-3.53 \pm 0.7$ & $2.45 *$ & $-0.44 \pm 0.4$ & $2 \pm 0.8$ & $2.44^{* * *}$ & $0.16 \pm 1.2$ & $2.34 \pm 0.5$ & 2.19 \\
\hline & SCO1187 celB & $1.86 \pm 0.2$ & $-3.23 \pm 0.7$ & $5.1 * *$ & $1 \pm 0.5$ & $-0.73 \pm 0.7$ & $1.73 *$ & $-0.71 \pm 0.4$ & $1.6 \pm 0.3$ & $2.3^{* *}$ \\
\hline & SCO6548 put beta-1,4-exocellulase & $3.72 \pm 0.4$ & $-2.76 \pm 0.2$ & $6.49^{* * *}$ & $0.54 \pm 0$ & $-1.36 \pm 0.4$ & $1.9^{* * *}$ & $-1.29 \pm 0.3$ & $0.85 \pm 0.8$ & 2.14 * \\
\hline & SCO7069 cbhH & $-0.84 \pm 0.3$ & $-3.14 \pm 1.4$ & 2.29 & $0.46 \pm 0.8$ & $1.6 \pm 0.6$ & 1.14 & $-0.13 \pm 0.9$ & $2.93 \pm 1.2$ & $3.06^{*}$ \\
\hline & SCO0481 chiG & $-1.32 \pm 0.3$ & $-2.7 \pm 0.4$ & $1.38 *$ & $-0.37 \pm 0.1$ & $1.94 \pm 0.6$ & $2.31^{* *}$ & $0.49 \pm 1.5$ & $1.96 \pm 0.9$ & 1.49 \\
\hline & SCO2758 nag $A$ & $1.41 \pm 0.1$ & $-0.88 \pm 0.3$ & $2.29^{* *}$ & $0.2 \pm 0$ & $-2.03 \pm 0.1$ & $2.23 * * *$ & $-0.89 \pm 0.4$ & $1.49 \pm 0.7$ & $2.39 *$ \\
\hline & SCO6712 laccase & $-0.74 \pm 0.4$ & $0.63 \pm 0.2$ & $1.36^{*}$ & $-0.88 \pm 0.1$ & $-0.97 \pm 0.5$ & 0.09 & $1.1 \pm 0.6$ & $0.3 \pm 1$ & 0.8 \\
\hline & SCO4284 NAG-6-P deacetylase & $0.27 \pm 0.2$ & $-0.92 \pm 0.1$ & $1.19^{* * *}$ & $0.03 \pm 0.2$ & $0.67 \pm 1$ & 0.64 & $-0.93 \pm 0.3$ & $0.88 \pm 0.3$ & $1.8^{* *}$ \\
\hline \multirow{7}{*}{ Metabolism } & SCO5236 nagB & $0.88 \pm 0.1$ & $-0.02 \pm 0.1$ & $0.9^{* * *}$ & $-0.86 \pm 0.1$ & $0.47 \pm 0.3$ & $1.33^{* *}$ & $-1.04 \pm 0.2$ & $1.14 \pm 0.3$ & $2.17^{* *}$ \\
\hline & SCO6535 narG & $-1.34 \pm 0.5$ & $-2.01 \pm 0.1$ & 0.67 & $0.6 \pm 1$ & $1.03 \pm 1$ & 0.43 & $-0.44 \pm 0.8$ & $2.17 \pm 0.5$ & $2.61^{*}$ \\
\hline & SCO2487 nirB & $-1.9 \pm 0.3$ & $-1.01 \pm 1.6$ & 0.89 & $-0.59 \pm 0.5$ & $2.03 \pm 0.7$ & $2.62 * *$ & $-0.55 \pm 0.9$ & $1.72 \pm 0.6$ & $2.27 *$ \\
\hline & SCO2488 nirC & $-1.29 \pm 0.3$ & $-2.16 \pm 0.3$ & $0.87 *$ & $-0.33 \pm 0$ & $1.14 \pm 0.6$ & $1.47^{*}$ & $-0.44 \pm 0.1$ & $2.05 \pm 0.9$ & 2.49 * \\
\hline & SCO4683 gdhA & $-0.08 \pm 0.2$ & $0.34 \pm 0.1$ & $0.42 *$ & $-0.94 \pm 0.8$ & $-0.57 \pm 0.5$ & 0.37 & $-1.06 \pm 0.6$ & $1.02 \pm 0.4$ & $2.09 *$ \\
\hline & SCO1942 pgi & $0.16 \pm 0.1$ & $0.61 \pm 0.2$ & $0.46^{*}$ & $-0.78 \pm 0.7$ & $0.22 \pm 0.1$ & 1 & $-0.14 \pm 1$ & $0.38 \pm 0.5$ & 0.52 \\
\hline & SCO5624 rpsB & $-0.02 \pm 0.2$ & $1.1 \pm 0.1$ & $1.08^{* *}$ & $0.27 \pm 0.2$ & $0.71 \pm 0.2$ & 0.44 & $-1.3 \pm 0.6$ & $-0.4 \pm 0.1$ & 0.9 \\
\hline
\end{tabular}


At $24 \mathrm{~h}$, the upregulated genes in the mung bean treatment were $g d h A, g l u D$, $p g i$, and $r p s B$ (Table 1). The $g d h A$ gene, which encodes the nicotinamide adenine dinucleotide phosphate (NADP)-specific glutamate dehydrogenase GDH, plays a central role in cellular $\mathrm{N}$ assimilation [20,34]. All potential $\mathrm{N}$ sources, for example, mineral $\mathrm{N}$, urea, $\mathrm{N}$-acetyl glucosamine, amino acids, and nucleotides were processed either extra- or intracellularly to form ammonium, which was subsequently utilised in the NADPH-dependent synthesis of glutamate via GDH. Glutamate (and to a lesser extent glutamine) acted as the sole organic $\mathrm{N}$ donors for $\mathrm{N}$ assimilation by the cell, and thus represent the bottleneck for cellular $\mathrm{N}$ assimilation [35]. The gluD gene partially encodes for a glutamate permease involved in the facilitated diffusion of extracellular glutamate into the cell, where it can also be utilised for cellular $\mathrm{N}$ assimilation [36]. The $p g i$ gene encodes for the glucose-6-phosphate isomerase, which is an essential enzyme in glycolysis. Finally, the $r p s B$ gene is a universally conserved, single-copy gene essential for protein synthesis [37] and was included as a marker to compare general cell activity between treatments. Thus, despite the upregulation of S. coelicolor A3(2) extracellular enzymes and mineral $\mathrm{N}$ metabolism to acquire additional $\mathrm{N}$ sources in response to the high $\mathrm{C}: \mathrm{N}$ ratio of wheat, the higher transcription of GDH facilitated the diffusion of extracellular glutamate into the cell. Moreover, glycolysis and higher potential protein synthesis indicate that $S$. coelicolor A3(2) was assimilating both $\mathrm{C}$ and $\mathrm{N}$ more effectively in the low C:N ratio mung bean treatment (Table 1). Figure 2 is a conceptual model of $\mathrm{S}$. coelicolor A3(2) metabolism after $24 \mathrm{~h}$ of incubation in response to the low C:N ratio mung bean residues, with metabolic intermediates and differentially-expressed proteins highlighted.

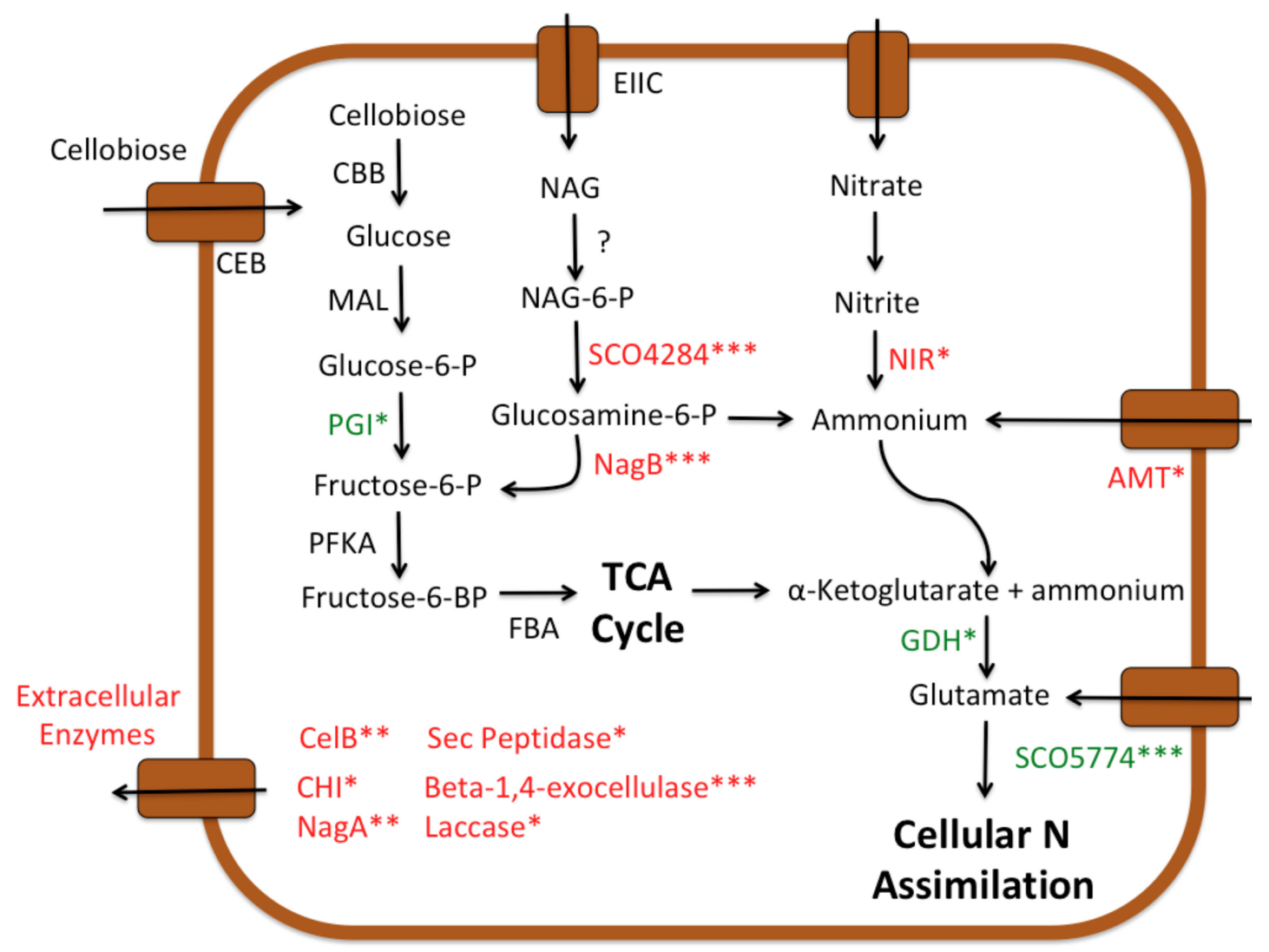

Figure 2. A conceptual model of changes in transcription in response to mung bean. Proteins labelled in green indicate significantly increased transcription, whereas red indicate significantly decreased transcription, for the comparison of wheat versus mung bean treatments with a Student's $t$-test after 24 h of incubation. $\left.{ }^{* * *}\right) p \leq 0.001 ;\left(^{* *}\right) p=0.001 ;\left(^{*}\right) p \leq 0.05$. The question mark refers to an unknown enzyme in S. coelicolor $\mathrm{A} 3(2)$. 
Interestingly, the expression of a peptidase, $c h i G$, and mineral $\mathrm{N}$ metabolism was reversed at day 7 and persisted up to day 14 , with the mung bean treatment demonstrating increases relative to wheat (Table 1). At 14 days, the majority of extracellular enzymes were significantly expressed in the mung bean treatment. Also worthy of note was a switch in extracellular glutamate uptake from the permease $g l u D$ at $24 \mathrm{~h}$ to the ATP-dependent glutamate ATP-binding cassette (ABC) transporter $g l u A$ at days 7 and 14, which may indicate that the extracellular glutamate was no longer in excess compared to intracellular glutamate. The expression of $\operatorname{rps} B$ remained relatively higher in the mung bean treatment over time, indicating higher general protein synthesis, however, it was not significant at days 7 and 14 (Table 1). These data indicate a delayed switch to $\mathrm{N}$ mining of SOM once labile, low C:N ratio plant material has likely been exhausted. While the mung bean treatment did demonstrate a delayed switch to nutrient mining, the exponentially decreasing rates of catabolism over time post substrate addition are a well-described phenomenon [11,38]; thus a delayed $\mathrm{N}$ mining effect seems preferable compared to an initial $\mathrm{N}$ mining effect in regard to retaining SOM.

The importance of $\mathrm{N}$ availability in regulating microbial metabolism has been explored thoroughly. The C:N ratio of the soil system, including plant material, is particularly important in determining both the formation and catabolism of SOM $[5,10,39]$. Initially, it was assumed that strict C:N stoichiometric controls would limit net decomposition i.e., $\mathrm{N}$ limitation would reduce heterotrophic activity, and conversely, $\mathrm{N}$ addition would increase net decomposition [40]. Numerous in situ studies demonstrated this to not necessarily be the case, suggesting that $\mathrm{N}$ addition inhibits the enzymes involved in lignin decomposition [41,42], resulting in the microbial community shifting away from the taxa directly involved in recalcitrant $C$ breakdown [13,43], or shifting microbial investment in extracellular enzyme activity away from $\mathrm{N}$ acquisition ( $\mathrm{N}$ mining) $[8,9,44]$. The increased expression of $\mathrm{N}$-acquiring chitinase, $\mathrm{N}$-acetyl glucosaminidase, and peptidases, as well as the increased expression of lignin-degrading laccase (a phenol oxidase) in the high C:N ratio wheat all agree with in situ studies that have demonstrated the increased activity of these enzymes under $\mathrm{N}$ limitation [44-48]. Interestingly, these studies also reported a general increase in C-acquiring cellobiohydrolase and glucosidase activity upon $\mathrm{N}$ addition, which did not occur here, as S. coelicolor A3(2) cellulase and cellobiohydrolase expression were also greater in the wheat at $24 \mathrm{~h}$ incubation. Given the simplified nature of this in vitro system that focused on the DGE of a model organism, it is possible that the response of these enzymes to $\mathrm{N}$ may be driven by other organisms within microbial communities. Thus, the relative importance of shifts in the composition of the microbial community in response to $\mathrm{N}$ addition may be enzyme-specific.

A potential means to reduce SOM losses from agricultural soils involves the reduction of the C:N ratio of the system, either through appropriate mineral and/or organic fertilisation [49-51] or crop rotations with $\mathrm{N}_{2}$-fixing plant species [52,53]. The results demonstrated here suggest a particularly important role for organic $\mathrm{N}$ in the form of glutamate. However, it should be noted that other important factors affect SOM turnover, including the molecular composition of the input plant material and both environmental and edaphic factors that regulate SOM accessibility $[6,54,55]$.

\section{Conclusions}

Here we demonstrate a suite of transcribed genes that are supportive of the $\mathrm{N}$ mining hypothesis. In short, under relatively N-limiting conditions, S. coelicolor A3(2) increased the transcription of genes involved in C and both organic and mineral N acquisition after $24 \mathrm{~h}$. Despite this, S. coelicolor A3(2) assimilated less cellular $\mathrm{N}$ through GDH and transcribed less transporters for glutamate uptake relative to non $\mathrm{N}$-limiting conditions. After 14 days, $\mathrm{N}$ mining had increased in the low $\mathrm{C}: \mathrm{N}$ ratio treatment as a delayed response to $\mathrm{N}$ requirements. This emphasises the importance of regulating the $\mathrm{C}: \mathrm{N}$ stoichiometry of the soil system in order to improve the management of SOM. 
Author Contributions: Author contributions are as follows: conceptualization, D.F., P.M.K. and R.C.D.; methodology, D.F.; software, D.F.; validation, D.F. and K.C.; formal analysis, D.F. and M.H.; investigation, D.F.; resources, D.O., A.V.K. and R.C.D.; data curation, D.F.; writing-original draft preparation, D.F.; writing-review and editing, P.M.K., A.V.K. and R.C.D.; visualization, D.F.; supervision, R.C.D.; project administration, R.C.D.; funding acquisition, R.C.D.

Funding: The authors wish to thank the Australian Commonwealth Department of Agriculture Farming and Futures Filling the Research Gap for funding.

Acknowledgments: The authors wish to acknowledge the helpful contributions of two anonymous reviewers, whose comments helped to improve the research.

Conflicts of Interest: The authors declare no conflicts of interest.

\section{References}

1. Murty, D.; Kirschbaum, M.U.F.; McMurtrie, R.E.; McGilvray, H. Does conversion of forest to agricultural land change soil carbon and nitrogen? A review of the literature. Glob. Chang. Biol. 2002, 17, 1658-1670. [CrossRef]

2. Ciais, P.; Sabine, C.; Bala, G.; Bopp, L.; Brovkin, V.; Canadell, J.; Chhabra, A.; DeFries, R.; Galloway, J.; Heimann, M.; et al. Carbon and other biogeochemical cycles. In Climate Change 2013: The Physical Science Basis. Contribution of Working Group I to the Fifth Assessment Report of the Intergovernmental Panel on Climate Change; Stocker, T.F., Qin, D., Plattner, G.K., Tignor, M., Allen, S.K., Boschung, J., Nauels, A., Xia, Y., Bex, V., Midgley, P.M., Eds.; Cambridge University Press: Cambridge, UK; New York, NY, USA, 2013.

3. FAO. Food and Agriculture Organization Chapter 5: Drivers of global soil changes. In Status of the World's Soil Resources (SWSR); Food and Agriculture Organization: Rome, Italy, 2015.

4. Hutchinson, J.J.; Campbell, C.A.; Desjardins, R.L. Some perspectives on carbon sequestration in agriculture. Agric. For. Meteorol. 2007, 142, 288-302. [CrossRef]

5. Cotrufo, M.F.; Wallenstein, M.D.; Boot, C.M.; Denef, K.; Paul, E. The Microbial Efficiency-Matrix Stabilization (MEMS) framework integrates plant litter decomposition with soil organic matter stabilization: Do labile plant inputs form stable soil organic matter? Glob. Chang. Biol. 2013, 19, 988-995. [CrossRef]

6. Schmidt, M.W.I.; Torn, M.S.; Abiven, S.; Dittmar, T.; Guggenberger, G.; Janssens, I.A.; Kleber, M.; Kogel-Knabner, I.; Lehmann, J.; Manning, D.A.C.; et al. Persistence of soil organic matter as an ecosystem property. Nature 2011, 478, 49-56. [CrossRef]

7. Six, J.; Conant, R.T.; Paul, E.A.; Paustian, K. Stabilization mechanisms of soil organic matter: Implications for C-saturation of soils. Plant Soil 2002, 241, 155-176. [CrossRef]

8. Craine, J.M.; Morrow, C.; Fierer, N. Microbial nitrogen limitation increases decomposition. Ecology 2007, 88, 2105-2113. [CrossRef]

9. Moorhead, D.L.; Sinsabaugh, R.L. A theoretical model of litter decay and microbial interaction. Ecol. Monogr. 2006, 76, 151-174. [CrossRef]

10. Zechmeister-Boltenstern, S.; Keiblinger, K.M.; Mooshammer, M.; Penuelas, J.; Richter, A.; Sardans, J.; Wanek, W. The application of ecological stoichiometry to plant-microbial-soil organic matter transformations. Ecol. Monogr. 2015, 85, 133-155. [CrossRef]

11. Finn, D.; Page, K.; Catton, K.; Strounina, E.; Kienzle, M.; Robertson, F.; Armstrong, R.; Dalal, R. Effect of added nitrogen on plant litter decomposition depends on initial soil carbon and nitrogen stoichiometry. Soil Biol. Biochem. 2015, 91, 160-168. [CrossRef]

12. Knicker, H. Soil organic N-An under-rated player for C sequestration in soils? Soil Biol. Biochem. 2011, 43, 1118-1129. [CrossRef]

13. Fierer, N.; Lauber, C.L.; Ramirez, K.S.; Zaneveld, J.; Bradford, M.A.; Knight, R. Comparative metagenomic, phylogenetic and physiological analyses of soil microbial communities across nitrogen gradients. ISME J. 2012, 6, 1007-1017. [CrossRef] [PubMed]

14. Mendes, L.W.; Brossi, M.J.D.; Kuramae, E.E.; Tsai, S.M. Land-use system shapes soil bacterial communities in Southeastern Amazon region. Appl. Soil Ecol. 2015, 95, 151-160. [CrossRef]

15. Wessen, E.; Hallin, S.; Philippot, L. Differential responses of bacterial and archaeal groups at high taxonomical ranks to soil management. Soil Biol. Biochem. 2010, 42, 1759-1765. [CrossRef]

16. Goodfellow, M.; Williams, S.T. Ecology of Actinomycetes. Ann. Rev. Microbiol. 1983, 37, 189-216. [CrossRef] [PubMed] 
17. Hopwood, D.A. Forty years of genetics with Streptomyces: From in vivo through in vitro to in silico. Microbiol. UK 1999, 145, 2183-2202. [CrossRef] [PubMed]

18. Bentley, S.D.; Chater, K.F.; Cerdeno-Tarraga, A.M.; Challis, G.L.; Thomson, N.R.; James, K.D.; Harris, D.E.; Quail, M.A.; Kieser, H.; Harper, D.; et al. Complete genome sequence of the model actinomycete Streptomyces coelicolor A3(2). Nature 2002, 417, 141-147. [CrossRef] [PubMed]

19. Hodgson, D.A. Primary metabolism and its control in Streptomycetes: A most unusual group of bacteria. Adv. Microb. Physiol. 2000, 42, 47-238. [PubMed]

20. Nieselt, K.; Battke, F.; Herbig, A.; Bruheim, P.; Wentzel, A.; Jakobsen, O.M.; Sletta, H.; Alam, M.T.; Merlo, M.E.; Moore, J.; et al. The dynamic architecture of the metabolic switch in Streptomyces coelicolor. BMC Genom. 2010, 11, 10. [CrossRef]

21. Rayment, G.; Lyons, D. Soil Chemical Methods-Australasia; CSIRO Publishing: Clayton, Australia, 2011.

22. Cassel, D.K.; Nielsen, D.R. Field capacity and available water capacity. In Methods of Soil Analysis, Part 1. Physical and Mineralogical Methods-Agronomy Monograph No. 9, 2nd ed.; Klute, A., Ed.; American Society of Agronomy-Soil Science Society of America: Madison, WI, USA, 1986; pp. 901-926.

23. Bank, T.L.; Kukkadapu, R.K.; Madden, A.S.; Ginder-Vogel, M.A.; Baldwin, M.E.; Jardine, P.M. Effects of gamma-sterilization on the physico-chemical properties of natural sediments. Chem. Geol. 2008, 251, 1-7. [CrossRef]

24. Berns, A.E.; Philipp, H.; Narres, H.D.; Burauel, P.; Vereecken, H.; Tappe, W. Effect of gamma-sterilization and autoclaving on soil organic matter structure as studied by solid state NMR, UV and fluorescence spectroscopy. Eur. J. Soil Sci. 2008, 59, 540-550. [CrossRef]

25. R Core Team. R: A Language and Environment for Statistical Computing; R Foundation for Statistical Computing: Vienna, Austria, 2017; ISBN 3-900051-07-0.

26. Bolger, A.M.; Lohse, M.; Usadel, B. Trimmomatic: A flexible trimmer for Illumina sequence data. Bioinformatics 2014, 30, 2114-2120. [CrossRef] [PubMed]

27. Langmead, B.; Salzberg, S.L. Fast gapped-read alignment with Bowtie 2. Nat. Methods 2012, 9, 357-359. [CrossRef]

28. Li, H.; Handsaker, B.; Wysoker, A.; Fennell, T.; Ruan, J.; Homer, N.; Homer, N.; Marth, G.; Abecasis, G.; Durbin, R. The Sequence Alignment/Map format and SAMtools. Bioinformatics 2009, 25, 2078-2079. [CrossRef]

29. Love, M.I.; Huber, W.; Anders, S. Moderated estimation of fold change and dispersion for RNA-seq data with DESeq2. Genome Biol. 2014, 15, 550. [CrossRef] [PubMed]

30. Venables, W.N.; Ripley, B.D. Modern Applied Statistics with S, 4th ed.; Springer: New York, NY, USA, 2002; ISBN 0-387-95457-0.

31. Ulanova, D.; Kitani, S.; Fukusaki, E.; Nihira, T. SdrA, a New DeoR Family Regulator Involved in Streptomyces avermitilis Morphological Development and Antibiotic Production. Appl. Environ. Microbiol. 2013, 79, 7916-7921. [CrossRef]

32. Castro-Melchor, M.; Charaniya, S.; Karypis, G.; Takano, E.; Hu, W.S. Genome-wide inference of regulatory networks in Streptomyces coelicolor. BMC Genom. 2010, 11, 578. [CrossRef]

33. Hoskisson, P.A.; Rigali, S.; Fowler, K.; Findlay, K.C.; Buttner, M.J. DevA, a GntR-like transcriptional regulator required for development in Streptomyces coelicolor. J. Bacteriol. 2006, 188, 5014-5023. [CrossRef]

34. Tiffert, Y.; Supra, P.; Wurm, R.; Wohlleben, W.; Wagner, R.; Reuther, J. The Streptomyces coelicolor GlnR regulon: Identification of new GlnR targets and evidence for a central role of GlnR in nitrogen metabolism in Actinomycetes. Mol. Microbiol. 2008, 67, 861-880. [CrossRef]

35. Reitzer, L.; Schneider, B.L. Metabolic context and possible physiological themes of sigma(54)-dependent genes in Escherichia coli. Microbiol. Mol. Biol. Rev. 2001, 65, 422-444. [CrossRef] [PubMed]

36. Li, L.; Jiang, W.; Lu, Y. A novel two component system, GluR-K, involved in glutamate sensing and uptake in Streptomyces coelicolor. J. Bacteriol. 2017. [CrossRef]

37. Gil, R.; Silva, F.J.; Peretó, J.; Moya, A. Determination of the core of a minimal bacterial gene set. Microbiol. Mol. Biol. Rev. 2004, 68, 518-537. [CrossRef] [PubMed]

38. Wang, W.J.; Baldock, J.A.; Dalal, R.C.; Moody, P.W. Decomposition dynamics of plant materials in relation to nitrogen availability and biochemistry determined by NMR and wet chemical analysis. Soil Biol. Biochem. 2004, 36, 2045-2058. [CrossRef] 
39. Manzoni, S.; Taylor, P.; Richter, A.; Porporato, A.; Agren, G.I. Environmental and stoichiometric controls on microbial carbon-use efficiency in soils. New Phytol. 2012, 196, 79-91. [CrossRef] [PubMed]

40. Hessen, D.O.; Ågren, G.I.; Anderson, T.R.; Elser, J.J.; de Ruiter, P.C. Carbon sequestration in ecosystems: The role of stoichiometry. Ecology 2004, 85, 1179-1192. [CrossRef]

41. Berg, B.; Matzner, E. Effect of $\mathrm{N}$ deposition on decomposition of plant litter and soil organic matter in forest systems. Environ. Rev. 1997, 5, 1-25. [CrossRef]

42. Fog, K. The effect of added nitrogen on the rate of decomposition of organic matter. Biol. Rev. 1988, 63, 433-462. [CrossRef]

43. Ramirez, K.S.; Craine, J.M.; Fierer, N. Consistent effects of nitrogen amendments on soil microbial communities and processes across biomes. Glob. Chang. Biol. 2012, 18, 1918-1927. [CrossRef]

44. Allison, S.D.; Vitousek, P.M. Responses of extracellular enzymes to simple and complex nutrient inputs. Soil Biol. Biochem. 2005, 37, 937-944. [CrossRef]

45. Sinsabaugh, R.L.; Carreiro, M.M.; Repert, D.A. Allocation of extracellular enzymatic activity in relation to litter composition, N deposition, and mass loss. Biogeochemistry 2002, 60, 1-24. [CrossRef]

46. Carreiro, M.M.; Sinsabaugh, R.L.; Repert, D.A.; Parkhurst, D.F. Microbial enzyme shifts explain litter decay responses to simulated nitrogen deposition. Ecology 2000, 81, 2359-2365. [CrossRef]

47. DeForest, J.L.; Zak, D.R.; Pregitzer, K.S.; Burton, A.J. Atmospheric nitrate deposition and the microbial degradation of cellobiose and vanillin in a northern hardwood forest. Soil Biol. Biochem. 2004, 36, 965-971. [CrossRef]

48. Saiya-Cork, K.R.; Sinsabaugh, R.L.; Zak, D.R. The effects of long term nitrogen deposition on extracellular enzyme activity in an Acer saccharum forest soil. Soil Biol. Biochem. 2002, 34, 1309-1315. [CrossRef]

49. Haynes, R.J. Labile organic matter fractions and aggregate stability under short-term, grass-based leys. Soil Biol. Biochem. 1999, 31, 1821-1830. [CrossRef]

50. Kirkby, C.A.; Richardson, A.E.; Wade, L.J.; Batten, G.D.; Blanchard, C.; Kirkegaard, J.A. Carbon-nutrient stoichiometry to increase soil carbon sequestration. Soil Biol. Biochem. 2013, 60, 77-86. [CrossRef]

51. Powlson, D.S.; Whitmore, A.P.; Goulding, K.W.T. Soil carbon sequestration to mitigate climate change: A critical re-examination to identify the true and the false. Eur. J. Soil Sci. 2011, 62, 42-55. [CrossRef]

52. Conant, R.T.; Paustian, K.; Elliott, E.T. Grassland management and conversion into grassland: Effects on soil carbon. Ecol. Appl. 2001, 11, 343-355. [CrossRef]

53. Lee, Z.M.; Schmidt, T.M. Bacterial growth efficiency varies in soils under different land management practices. Soil Biol. Biochem. 2014, 69, 282-290. [CrossRef]

54. Dungait, J.A.; Hopkins, D.W.; Gregory, A.S.; Whitmore, A.P. Soil organic matter turnover is governed by accessibility not recalcitrance. Glob. Chang. Biol. 2012, 18, 1781-1796. [CrossRef]

55. Finn, D.; Page, K.; Catton, K.; Kienzle, M.; Robertson, F.; Armstrong, R.; Dalal, R. Ecological stoichiometry controls the transformation and retention of plant-derived organic matter to humus in response to nitrogen fertilisation. Soil Biol. Biochem. 2016, 99, 117-127. [CrossRef]

(C) 2018 by the authors. Licensee MDPI, Basel, Switzerland. This article is an open access article distributed under the terms and conditions of the Creative Commons Attribution (CC BY) license (http:/ / creativecommons.org/licenses/by/4.0/). 